\title{
Exchange Rate Regimes and Economic Growth in Nigeria
}

\author{
Mathias A. Chuba ${ }^{1 *} \quad$ Wilson Ebhotemhen ${ }^{2}$ \\ 1.Department of Economics, Achievers University, Owo, Ondo State, Nigeria \\ 2.Department of Economics, Edo University, Iyamho, Edo State, Nigeria
}

\begin{abstract}
In view of the fact that economic theory does not clearly identify which kind of exchange rate regime would be more likely to promote economic growth, this paper seeks to determine the differential impact of exchange rate policy on economic growth in Nigeria under a fixed and a flexible exchange rate regimes from 1973 to 2017 using the dummy variable regression model. The annual time series data of the variables that are used in the estimation of the model are obtained from The World Bank: The World Tables, 1974 and World Bank World Development Indicators. The differential intercept is positive but statistically insignificant and differential slope coefficient is positive and statistically significant, strongly suggesting that the exchange rate-economic growth regressions for the fixed and flexible exchange rate regimes are different. The slope coefficient for a flexible exchange rate regime is greater than the slope coefficient for a fixed exchange rate regime by 7.8472 units. The calculated F-statistic is greater than the tabulated F-statistic at 5 percent level of significance and at 6 and 38 degrees of freedom. This implies that there is an evidence of structural instability. The regression coefficient of exchange rate is positive and statistically significant. The result shows that the switch from a fixed exchange rate regime to a flexible exchange rate regime leads to an increase in exchange rate and the depreciation of exchange rate has significant positive impact on economic growth in Nigeria. A flexible exchange rate regime would promote economic growth more than a fixed exchange rate regime. We recommend the sustainability of a flexible exchange rate regime that has been in operation since 1986 in order to increase economic growth in Nigeria.
\end{abstract}

Keywords: Exchange rate regimes, Economic growth, Dummy variable regression model, Secondary data, Nigeria

DOI: $10.7176 / \mathrm{JESD} / 10-18-19$

Publication date:September $30^{\text {th }} 2019$

\section{Introduction}

The catalogue of the structural distortions in the economy, which is adequately documented in the literature, made Nigeria to embark on a vigorous programme of adjustment and reform beginning from 1986. The core objectives of the adjustment and reform programme include the adoption of a realistic foreign exchange rate policy, stimulation of domestic production and broadening of the supply base of the economy, improved trade and payment liberalization and the privatization of public sector enterprises among others (Soludo, 1993). Under the structural adjustment programme which was implemented from July1986, the exchange rate strategy was to float the naira and establish an institutional framework for its trading in a market-determined environment (Obadan, 2006).

From a theoretical perspective, both growth theory and the literature on exchange rate regimes suggest that the type of exchange rate adopted by a country could have consequences for its medium term growth, both directly, through its effects on the adjustment to shocks, and indirectly, via its impact on other important determinants of growth, such as investment, international trade, capital flows, and financial sector development. Economic theory, however, does not clearly identify which kind of exchange rate regime would be more likely to promote growth (Bailliu et al., 2002). Consequently, the choice of exchange rate regime that a country should adopt in order to achieve economic growth has become the main subject of debate among economists. This debate can only be resolved through empirical study. Therefore, exchange rate regimes and economic growth in Nigeria is an important topical issue.

There are previous studies on exchange rate regimes and economic growth in Nigeria. The results of these previous studies are mixed. For example, while Obi et al. (2016) find that fixed and flexible exchange rate regimes constrain and spur economic growth in Nigeria respectively, Eze and Okpala (2014) find that the relationship between exchange rate and economic growth performance in Nigeria has not undergone any significant structural changes. The differences in research findings are not unconnected to the inappropriate methodologies that are employed by these previous researchers. This study is necessary in order to reconcile the previous research findings.

In view of the above statement of the problem, this study is guided by the following research question. Does a switch from a fixed exchange rate regime to a flexible exchange rate regime leads to an increase in economic growth in Nigeria? In other words, what is the differential impact of exchange rate policy on economic growth in Nigeria under a fixed exchange rate regime and a flexible exchange rate regime? The main objective of this paper is to determine the differential impact of exchange rate policy on economic growth in Nigeria under the fixed and flexible exchange rate regimes. The hypothesis to be tested is that there is no differential impact of exchange rate 
policy on economic growth in Nigeria under the fixed and flexible exchange rate regimes. This paper consists of five sections. The next section is literature review. Section 3 presents the methodology. The results are discussed in section 4 and conclusions are drawn in section 5.

\section{Literature Review}

According to IMF de facto classification, exchange rate arrangements can be classified into four categories: hard pegs or fixed regimes (such as currency board arrangements), soft pegs or intermediate regimes (such as crawling pegs, stabilized arrangements, and craw-like arrangements), floating regimes (such as managed floating and free floating), and residuals (IMF, 2013: 4). Under fixed exchange rate, local currency is either pegged against another currency or a basket of other currencies. When the monetary authority decides to fix exchange rates against other currencies, it makes a commitment to intervene in the market, buying and selling its currency whenever necessary to keep the exchange rate from changing. Within flexible exchange rate regime, the value of currency is allowed to fluctuate based on the supply and demand of that particular currency in the foreign exchange market. In reality, the implementations of exchange rate regimes are not always about choosing the other end of spectrum. Most countries adopt a variety of combinations of both fixed and floating regimes, which are called intermediate regimes. One type of intermediate regimes is the crawling peg, where a currency value is allowed to fluctuate within a certain limit (Jakob, 2016).In Nigeria, the exchange rate policy has undergone substantial transformation from the immediate post-independence period in 1960 when the country maintained a fixed parity with the British pound, through the oil boom of the 1970s, to the floating of the currency in (since) 1986, following the near collapse of the economy between 1982 and 1985 period (Akpan and Atan 2012).

The literature on exchange rate regimes suggests that the type of regime chosen could influence growth in two main ways: directly, through its effects on the adjustment to shocks, and indirectly, if it affects other control variables such as investment, openness to international trade, capital flows, and financial sector development. First, one can justify considering the exchange rate regime as a control variable in a growth regression because of its potential role in influencing growth through the extent to which a regime may assuage or amplify the impact and adjustment to economic shocks. The literature on exchange rate regimes has emphasized how an economy's adjustment process following a shock can differ based on the nature of the exchange rate regime. It has been argued that a more flexible arrangement may foster higher growth, since it will enable an economy characterized by nominal rigidities to absorb and adapt to economic shocks more easily, because exchange rate movements can act as shock absorbers. A flexible exchange rate regime also allows a country to have an independent monetary policy, providing the economy with another means to accommodate domestic and foreign shocks. When the adjustment to shocks is smoother, one would expect growth to be higher, given that the economy is, on average, operating closer to capacity. A more flexible arrangement is also less likely to generate persistent misalignments in foreign exchange markets, which may result in an economic crisis. Thus, an important reason why pegged exchange rate regime may be deleterious to growth is that it tends to break down. Countries suffering from frequent economic crises are likely to experience, on average, lower growth (Bailliu, et al. 2002).Some (e.g., Hausmann et al. 1999) argue that a flexible exchange rate regime is more prone to exchange rate shocks. Thus, they would argue, the introduction of this additional source of shocks to the economy under a flexible exchange rate regime might exacerbate the business cycle and dampen growth more than a fixed exchange rate regime.

Second, the type of regime chosen could influence growth indirectly if it affects other determinants of economic growth, such as investment, openness to international trade, capital flows, and financial sector development. Exchange rate regimes can influence economic growth through their effects on the rate of physical capital accumulation (Bailliu et al. 2002). Some (e.g., Aizenman 1994) would argue that investment will tend to be higher under a fixed exchange rate regime as a result of a reduction in policy uncertainty, real interest rates, and exchange rate variability. On the other hand, by eliminating an important adjustment mechanism, fixed exchange rate regime can exacerbate protectionist pressures and reduce the efficiency of a given stock of capital, as well as result in misalignments that distort the efficient allocation of investment across sectors. Bohm and Funke (2001) argue that currency volatility, regardless of the nature of the exchange rate regime, may exert only a small influence upon the level of investment spending.

The degree of openness of the economy to international markets is also believed to influence economic growth The endogenous growth literature has established a positive link between openness to international trade and economic growth, in line with the belief that countries that are more open to international trade will tend to grow more rapidly, because they have developed a greater ability to absorb technological advances and take advantage of larger markets (Edwards 1993, Barro and Sala-i-Martin 1995). In addition, there may be positive spillovers to the non-tradable sector. Thus, to the extent that the nature of the exchange rate regime influences the volume of international trade, this could translate into an effect on growth (Bailliu, et al. 2002). The literature suggests that international trade is influenced by the type of exchange rate regime, but it does not clearly predict which regime is more likely to foster international trade. It has been suggested that trade should be higher under fixed regimes, since exchange rate volatility and uncertainty will be lower, which will tend to reduce the cost of trade and, hence, 
increase its volume. While the notion that exchange rate volatility is detrimental to trade is intuitively appealingbecause it can increase business risks and disturb planning-the effect on trade is not obvious once firms are allowed to diversify across markets, source inputs from both home and abroad, adopt flexible invoicing arrangements, or have access to hedging instruments. The more flexible regimes can favour export growth, because, for example, they are less likely to create conditions for persistent misalignments (Nilsson and Nilsson, 2000).

The openness to international capital flows can also be an important engine of growth. As emphasized by Bailliu (2000), international capital flows can promote growth by increasing the domestic investment rate, by leading to investments associated with positive spillovers, and/or by increasing domestic financial intermediation. The nature of the exchange rate regime can influence economic growth indirectly if it affects the volume or composition of international capital flows. It has been argued (e.g., Dooley 1994) that a fixed or quasi-fixed exchange rate regime, when coupled with regulatory distortions and/or prudential oversight, can be associated with an increase in speculative capital flows.

A sound and well-developed financial sector is important for economic growth, regardless of the type of exchange rate regime. A large body of work, reviewed by Levine (1997), has shown how the existing level of development of the financial system-reflected in its ability to exercise functions such as mobilizing savings, helping to allocate capital, and facilitating risk management-can promote growth through its effects on capital accumulation. A more developed financial system can promote growth by increasing the efficiency with which savings are allocated to investment and/or by improving the allocation of capital. The exchange rate regime could influence growth through its effects on the level of development of financial markets. Flexible arrangements are generally associated with increased nominal exchange rate volatility, which can have damaging effects on the real economy unless the financial sector can absorb exchange rate shocks and provide agents with appropriate hedging instruments. Thus, it is sometimes argued that an economy must have a reasonably well-developed domestic financial system to benefit from a flexible exchange rate regime. Many emerging-market economies have shallow capital markets, and hence may find it difficult to manage a flexible exchange rate regime. However, the combination of an underdeveloped financial sector and a fixed exchange rate regime can also be problematic, because it can result in a banking crisis (Bailliu et al. 2002). As Chang and Velasco (2000) argue, a hard peg may make balance-of-payments crises less likely only by making banking crises more likely.

From the theoretical literature, we have the following observations. Bailliu et al. (2002) do not explain how the type of exchange rate regime chosen could affect exchange rate and net exports. The type of exchange rate regime chosen could influence growth indirectly, if it affects exchange rates and net exports. The flexible exchange rate regime is associated with increased nominal exchange rate volatility than the fixed exchange rate regime. In other words, the flexible exchange rate regime is more associated with exchange rate depreciation than the fixed exchange rate regime. Hence, net exports are higher under the flexible exchange rate regime than the fixed exchange rate regime. According to McConnell and Brue (2005: 197), exchange rate depreciation leads to an increase in economic growth through an increase in net exports and aggregate demand. The following illustrations illuminate how exchange rate depreciation can lead to an increase in economic growth through an increase in net exports and aggregate demand. If naira depreciates in terms of the dollar, this means that the dollar appreciates in terms of the naira. The new relatively lower value of naira and higher value of dollars makes American buyers to obtain more naira with each dollar. Consequently, Nigerian goods become less expensive because fewer dollars can be used to obtain them. This enables American buyers to purchase more Nigerian goods and so Nigerian exports rise. On the other hands, Nigerian buyers can now obtain fewer dollars with each naira. This makes Nigerian buyers to pay more naira to purchase American goods. Therefore, American goods become more expensive because more naira can now be used to obtain them. This makes Nigerians to reduce their imports. The depreciation of naira causes Nigerian exports to rise. It also causes Nigerian imports to fall. The rise in exports and a fall in imports lead to an increase in net exports. According to Keynes (1936), a rise in net exports leads to an increase in aggregate demand and an increase in net exports and aggregate demand lead to an increase in economic growth through the multiplier effect. Since net exports are higher under the flexible exchange rate regime than the fixed exchange rate regime, aggregate demand and economic growth are higher under the flexible exchange rate regime than the fixed exchange rate regime. In view of the above observations, the type of exchange rate regime chosen could influence growth indirectly, if it affects other control variables such as exchange rate, investment, net exports, openness to international trade, capital flows and financial sector development.

A number of studies have been conducted on the impact of exchange rate regimes on economic growth in both developing and advanced economies. For example, Jakob (2016) investigates the impact of exchange rate regimes on economic growth in 74 countries (36 developed and 38 developing countries) for the year of 2012. Control variables used in that study include inflation rate, gross capital formation (\% GDP), index of government spending, and index of human capital per person. After observing the data, it is found that there is a positive and significant correlation between pegged exchange rate and growth in GDP.

Bailliu et al. (2002) estimate the impact of exchange rate regimes on economic growth in a panel-data set of 60 countries from 1973 to 1998 using a dynamic generalized method of moments estimation technique. They find 
evidence that exchange rate regimes characterized by a monetary policy anchor, whether they are pegged, intermediate, or flexible, exert a positive influence on economic growth. They also find evidence that intermediate/flexible regimes without an anchor are detrimental for growth. Their results suggest that it is the presence of a strong monetary policy framework, rather than the type of exchange rate regime per se, that is important for economic growth. Furthermore, their work emphasizes the importance of considering the monetary framework that accompanies the exchange rate arrangement when assessing the macroeconomic performance of alternative exchange rate regimes.

Stotsky et al. (2012) examine the relationship between the foreign exchange regime and macroeconomic performance in Eastern Africa. The study focuses on seven countries, five of which decisively liberalized their foreign exchange regimes. The study assesses the relationship between (i) growth and various determinants, including the exchange regime, the real exchange rate, and current account liberalization; and (ii) inflation and various determinants, including lagged inflation, the nominal exchange rate, the exchange regime, and liberalization. They find that in their sample, for the determinants of growth, investment and the real exchange rate are significant determinants but not the exchange regime or liberalization; and for inflation, the lagged inflation rate, nominal exchange rate, and the de facto regime are significant. Exchange rate pass-through is limited.

Ghosh et al. (1997) provides a descriptive analysis (means and standard deviation comparisons across regimes) of the growth performance under alternative regimes in 145 IMF-member countries for 30 years after 1960 and found a slightly higher GDP growth under a float (1.7\% under floating compared to $1.4 \%$ under a peg). The study concludes that as investment rates contributed two percentage points of GDP, then the lower output growth under a peg must be a result of a slow productivity growth. Higher productivity growth under a float also supported the growth of external trade. However, the evidence is not overwhelming. Surprisingly, growth appeared to be the highest $(2 \%)$ under an intermediate regime (soft pegs of managed float). Switching to a floating regime resulted to improved growth by 1 percentage points.

Moreno (2001) in his study, using descriptive statistics, measured how the regime (actual behaviour) affected GDP growth and volatility on a sample of 98 developing countries and East-Asian countries, respectively, over the period 1974-1999. His work supports the view that real growth used to be higher under a peg by $1.1 \%$ and $3 \%$ respectively. The difference is robust to excluding the periods of currency crises preceded by a peg and excluding the top $1 \%$ high-inflation episodes.

Levy-Yeyati and Sturzenegger (2003) in their study of to float or fix: evidence on the impact of exchange rate regime on growth using a new de facto classification of regimes based on the actual behaviour of the relevant macroeconomic variables found out that for developing countries, less flexible exchange rate regimes are associated with slower growth, as well as with greater output volatility and for industrial countries, regimes do not appear to have any significant impact on growth.

Huang and Malhorta (2004) examine the relationship between exchange-rate regime and growth by paying attention on two aspects: exchange-rate-regime classification and differentiation between developing and developed economies. The study uses 12 developing Asian countries and 18 advanced European economies over the period 1976-2001. It utilizes descriptive statistics and regression variables such as per capita growth, financial crisis; openness; government consumption; initial GDP; fertility rate; secondary school enrolment ratio; and exchange rate dummies. Findings suggest that the exchange-rate regime matters for developing economies: fixed and managed floating regimes outperform the others in terms of growth. However, for advanced economies, no significant regularity is discovered.

Miles (2006) in a study titled to float or not to float? Currency regimes and growth using panel regressions argue that the effect of fixed exchange rates on growth in emerging markets is not direct, but rather contingent on the existence of macroeconomic imbalances and other distortions in place in the domestic economy. For him these results seem to conform more closely with exchange rate theory, which posits mostly positive, and few negative channels for pegged currencies to impact growth over the long run.

The study of Bleaney and Francisco (2007) also pays attention to the regime classification. It utilizes de-facto classification carried out by previous studies, including 91 developing countries over the period 1984- 2001. They regress the growth rate on its lagged value, exchange-rate dummies and time dummies and exclude high inflationperiods. Findings are that pegs are associated by significantly slower growth than soft pegs or floats.

Yougbaré (2008) carried an empirical reappraisal of the linkages between growth, volatility and the exchange rate system. The results reveal that fixed exchange regimes raise growth in a heterogeneous manner, the impact being concentrated at lower growth rates. As regard the second goal, pegged exchange systems are shown to amplify the negative direct and indirect growth-effects of volatility. All in all, the findings suggest that fixed exchange rates constrain the ability of the economy to adjust to shocks and volatility.

Eze and Okpala (2014) examine the impact of the two basic exchange rate policies, namely, the fixed and flexible regimes on economic growth in Nigeria from 1970-2011 using the Chow test. The estimated result reveals that, apart from government expenditure, both exchange rate and money supply are highly significant in the determination of Nigeria's economic growth performance. The conducted Chow test shows that the relationship 
between exchange rate and economic growth performance in Nigeria has not undergone any significant structural changes. The implication is that no matter the exchange rate regime, whether fixed or flexible, what matters for growth is the effectiveness of the management of exchange rate policy.

Obi et al. (2016) examine the relationship between exchange rate regimes and output growth in Nigeria in different periods from 1970 to 2014. The study employs the Generalized Method of Moments (GMM) to estimate economic growth equation as a result of endogeneity problem. The real GDP, real exchange rate, broad money supply $\left(\mathrm{M}_{2}\right)$, total government spending and degree of openness to international trade are the variables that are included in their model. Their study suggests that exchange rate regimes indeed matter in terms of real economic performance in Nigeria as the results reveal that fixed and flexible exchange rate regimes constrain and spur economic growth in Nigeria respectively. It is against this background, that they recommend the sustainability of the regime of exchange rate liberalization that has been in operation from 1986.

Eneji et al. (2018) investigate the effect of exchange rate policy and its volatility on economic growth in Nigeria from 1996-2017 using a dynamic distributed-lag model. The results show a negative relationship between exchange rate volatility and economic growth. The followings are the weaknesses of previous studies. Eneji et al. (2018) investigate the effect of exchange rate policy and its volatility on economic growth in Nigeria from 19962017. The periods of fixed and flexible exchange rate regimes in Nigeria are 1960-1985 and 1986-2019 respectively. These researchers have excluded the period of fixed exchange rate regime from their study. The scope of a research topic on the effect of exchange rate policy on economic growth in Nigeria should include both the periods of fixed and flexible exchange rate regimes. Moreover, the pooled regression from 1996-2017 which they employed in their study is not an appropriate method because it disregards possible differences in the two subperiods. They could not determine the impact of exchange rate regimes on economic growth in Nigeria.

Obi et al. (2016) investigate the impact of exchange rate regimes on economic growth in Nigeria from 19702014 using a Generalized Method of Moments (GMM). They estimated three regression equations in order to achieve their objective. The first regression equation is for the period of fixed exchange rate regime, 1970-1985. The second regression equation is for the period of flexible exchange rate regime, 1986-2014 and the third regression equation is the pooled regression for the period, 1970-2014. It is not necessary to estimate three separate regression equations for the three periods in order to achieve their objective. The objective of their study can be achieved with just one dummy variable regression model.

Eze and Okpala (2014) investigate the impact of exchange rate regimes on economic growth in Nigeria from 1970-2014 using Chow test. The Chow test only tells us if the two regressions are different, without telling us whether the difference is on account of the intercept terms, or the slope coefficients, or both. The dummy variable regression model tells us if the two regressions are different and whether the difference is on account of the intercepts, or the slopes, or both. This is why the dummy variable regression technique is pre fared to Chow test in the determination of the structural or parameter change that is attributed to policy changes.

Eze and Okpala (2014) and Obi et al. (2016) in their investigation of the relationship between exchange rate regimes and economic growth in Nigeria use Chow test and Generalized Method of Moments respectively and obtained mixed results. Eze and Okpala (2014) find that exchange rate regimes do not matter for growth. Obi et al. (2016) find that fixed and flexible exchange rate regimes constrain and spur growth respectively. In order to reconcile the previous research findings, this study uses a dummy variable regression technique to estimate the differential impact of exchange rate policy on economic growth in Nigeria under the fixed and flexible exchange rate regimes.

\section{Methodology}

This study uses a dummy variable regression technique following Huang and Malhorta (2004) and Bleaney and Franscisco (2007) in determining the effects of alternative exchange rate regimes on economic growth. The use of dummy variable can be considered as a test of stability of the estimated parameters in a regression equation. When an equation includes both a dummy variable for the intercept and a multiplicative dummy variable for each of the explanatory variables, the intercept and each partial slope is allowed to vary, implying different underlying structures for the two conditions ( 0 and 1 ) associated with the dummy variable. Therefore, using dummy variables is like conducting a test for structural stability. In essence, two different equations are being estimated from the coefficients of a single equation. In this study the differential impact of exchange rate policy on economic growth in Nigeria is estimated using a dummy variable regression technique.

The capital flows are mainly used to finance investment and so both variables are highly correlated to each other. Therefore, including capital flows and investment simultaneously in a growth equation can lead to the problem of multicollinearity because of a very high inter-correlations or inter-associations between these two independent variables. In order to avoid the problem of multicollinearity and to ensure that the statistical inferences that are made about the data are reliable, we step-down capital flows for investment in the growth equation because investment is the link through which capital flows affect economic growth. The literature on exchange rate regimes suggests that the type of regime chosen could influence growth indirectly, if it affects openness to international 
trade and net exports but we believe that net exports is the link through which the type of regime chosen could influence economic growth. Thus, the dummy variable regression equation is specified as follows:

$\mathrm{D}(\mathrm{LGDP})=\beta_{0}+\beta_{1} \mathrm{DUM}+\beta_{2} \mathrm{D}(\mathrm{LEXR})+\beta_{3} \mathrm{D}(\mathrm{LGDI})+\beta_{4} \mathrm{D}(\mathrm{LNEX})+\beta_{5} \mathrm{D}(\mathrm{LFSD})+$ $\beta_{6} \mathrm{D}[\mathrm{L}(\mathrm{DUM} * \mathrm{EXR} * \mathrm{GDI} * \mathrm{NEX} * \mathrm{FSD})]+\mathrm{U}_{\mathrm{t}}$

Where GDP is gross domestic product (current LCU), DUM is dummy variable, EXR is official exchange rate (current LCU per US\$, period average), GDI is gross domestic investment, i.e. gross capital formation (current LCU), NEX is net exports, i.e. external balance on goods and services (current LCU), FSD is financial sector development, i.e. domestic credit to private sector by banks ( $\%$ of GDP), $U_{t}$ is error term, D is first difference operator, $\mathrm{L}$ is logarithm, $\beta_{0}$ is intercept, $\beta_{1}$ is differential intercept, $\beta_{6}$ is differential slope coefficient (slope drifter). The specification of the model is based on the growth literature discussed in section 2 . The literature provides the guide in the selection of the appropriate explanatory variables. The effects of exchange rate, gross domestic investment, net exports, and financial sector development on growth domestic product, a proxy of economic growth are all expected to be positive, as discussed in section 2 . The effect of dummy variable on economic growth may be negative, zero or positive.

The differential intercept indicates how much the intercept of the second period's GDP function (the category that receives the dummy value of 1) differs from that of the first period. The differential slope coefficient indicates how much the slope coefficient of the second period's GDP function (the category that receives the dummy value of 1) differs from that of the first period. Dummy variable $=0$ for observations in 1973-1985 and dummy variable $=1$ for observations in 1986-2017. While 1 indicates the presence of a flexible exchange rate system, 0 indicates the absence of a flexible exchange rate system.

The dummy variable regression equation is estimated using e-view 7.0. The time series properties of the data are analyzed using the Augmented Dickey-Fuller (ADF) unit root test of Dickey and Fuller (1979). Test of cointegration is carried out using the Johansen (1988) maximum likelihood procedure.

The empirical analysis is conducted using annual data. The time span covered is 1973 to 2017. The choice of 1973 as the base year is due to the fact that the data of gross domestic investment are not available from 1960 to 1972. The choice of 2017 as the terminal year is premised on the fact that the data required for the study can only be obtained up to that year. The data of gross domestic investment from 1973 to 1980 are obtained from The World Bank: The World Tables, 1974. All the other data are obtained from World Bank World Development Indicators (WDI). The data for all the variables are not in the same unit of measurement. Therefore, the data for all the variables are transformed to logarithms in order to be of the same standard.

\section{Results}

4.1. Pre-Estimation Tests

The unit root test was conducted using Augmented Dickey-Fuller (ADF) test (Table 1). All the variables are nonstationary at levels because ADF-statistic is less than test critical value in absolute terms at 5 percent level and pvalue of each variable is greater than 5 percent. All the variables are stationary at first differences because ADFstatistic is greater than test critical value in absolute terms at 5 percent level and p-value is less than 5 percent. The $\mathrm{ADF}$ test indicates that all the variables are integrated at order one at 5 percent level.

Table 1. Augmented Dickey-Fuller Test

\begin{tabular}{|c|c|c|c|c|c|}
\hline \multirow[t]{2}{*}{ Variables } & \multicolumn{2}{|l|}{ Levels } & \multicolumn{2}{|c|}{ First Differences } & \multirow{2}{*}{$\begin{array}{ll}\text { Order } & \text { of } \\
\text { Integration } & \\
\end{array}$} \\
\hline & ADF-Statistic & Prob* & ADF- Statistic & Prob* & \\
\hline LGDP & -0.3977 & 0.9006 & -6.0715 & 0.0000 & $\mathrm{I}(1)$ \\
\hline LEXR & -0.4259 & 0.8956 & -5.4269 & 0.0000 & $\mathrm{I}(1)$ \\
\hline LGDI & 0.1698 & 0.9675 & -5.3803 & 0.0001 & $\mathrm{I}(1)$ \\
\hline LNEX & -2.3509 & 0.1626 & -3.1531 & 0.0319 & $\mathrm{I}(1)$ \\
\hline LFSD & -2.8939 & 0.0543 & -4.4274 & 0.0010 & $\mathrm{I}(1)$ \\
\hline
\end{tabular}

Test critical values: $1 \%$ level -3.6394

$5 \%$ level -2.9511

$10 \%$ level -2.6143

*Mackinnon (1996) one sided p-values

Source: Authors' Computation.

The co-integration test was conducted using Johansen test for co-integration vectors (Table 2). The trace statistic is greater than 0.05 Critical Value and p-value is less than 5 percent for none to three (3) hypothesized number of co-integrating equations. The maximum eigenvalue statistic is greater than 0.05 Critical Value and pvalue is less than 5 percent for none to (3) hypothesized number of co-integrating equations. Both trace and maximum eigenvalue tests denote rejection of no co-integration at 5 percent level. Both trace and maximum eigenvalue tests indicate 4 co-integrating equations at 5 percent level. 
Table 2. Johansen Test for Co-integration Vectors

\begin{tabular}{|c|c|c|c|c|c|c|}
\hline \multirow{2}{*}{$\begin{array}{l}\text { Hypothesized } \\
\text { No. of CE (s) }\end{array}$} & \multicolumn{3}{|l|}{ Trace } & \multicolumn{3}{|c|}{ Maximum Eigenvalue } \\
\hline & $\begin{array}{l}\text { Trace } \\
\text { Statistic }\end{array}$ & $\begin{array}{l}0.05 \text { Critical } \\
\text { Value }\end{array}$ & Prob** & $\begin{array}{l}\text { Max-Eigen } \\
\text { Statistic }\end{array}$ & $\begin{array}{l}0.05 \text { Critical } \\
\text { Value }\end{array}$ & Prob** \\
\hline None* & 161.9717 & 69.8189 & 0.0000 & 64.4895 & 33.8769 & 0.0000 \\
\hline At most $1^{*}$ & 97.4823 & 47.8561 & 0.0000 & 42.4044 & 27.5843 & 0.0003 \\
\hline At most $2^{*}$ & 55.0778 & 29.7971 & 0.0000 & 32.3669 & 21.1316 & 0.0009 \\
\hline At most 3* & 22.7109 & 15.4947 & 0.0034 & 19.3110 & 14.2646 & 0.0073 \\
\hline At most 4 & 3.3999 & 3.8415 & 0.0652 & 3.3999 & 3.8415 & 0.0652 \\
\hline
\end{tabular}

*denotes rejection of the hypothesis at the 0.05 level

** Mackinnon- Haug- Michelis (1999) p-values

Source: Authors' Computation.

\subsection{Post-Estimation Tests}

The dummy variable regression model assumes that there is no autocorrelation between the error terms. The Durbin-Watson statistic is used to verify the assumption of no serial correlation, or no autocorrelation. In an application, if Durbin-Watson statistic is approximately equal to 2, one can accept the hypothesis that there is no residual autocorrelations. The dummy variable regression results of D(LGDP) in table 3 shows that Durbin-Watson statistic is 1.542 which is approximately equal to 2 . This result shows that there is no autocorrelation between the error terms.

The Cusum of Squares test is used to verify whether the dummy variable regression model is stable. The dummy variable regression model is stable if the Cusum of Squares lies within 5 percent critical bound dotted lines. As we can see in Figure 1, the Cusum of Squares lies within 5 percent critical bound dotted lines. The Cusum of Squares test indicates that the dummy variable regression model is stable at 5 percent level of significance.

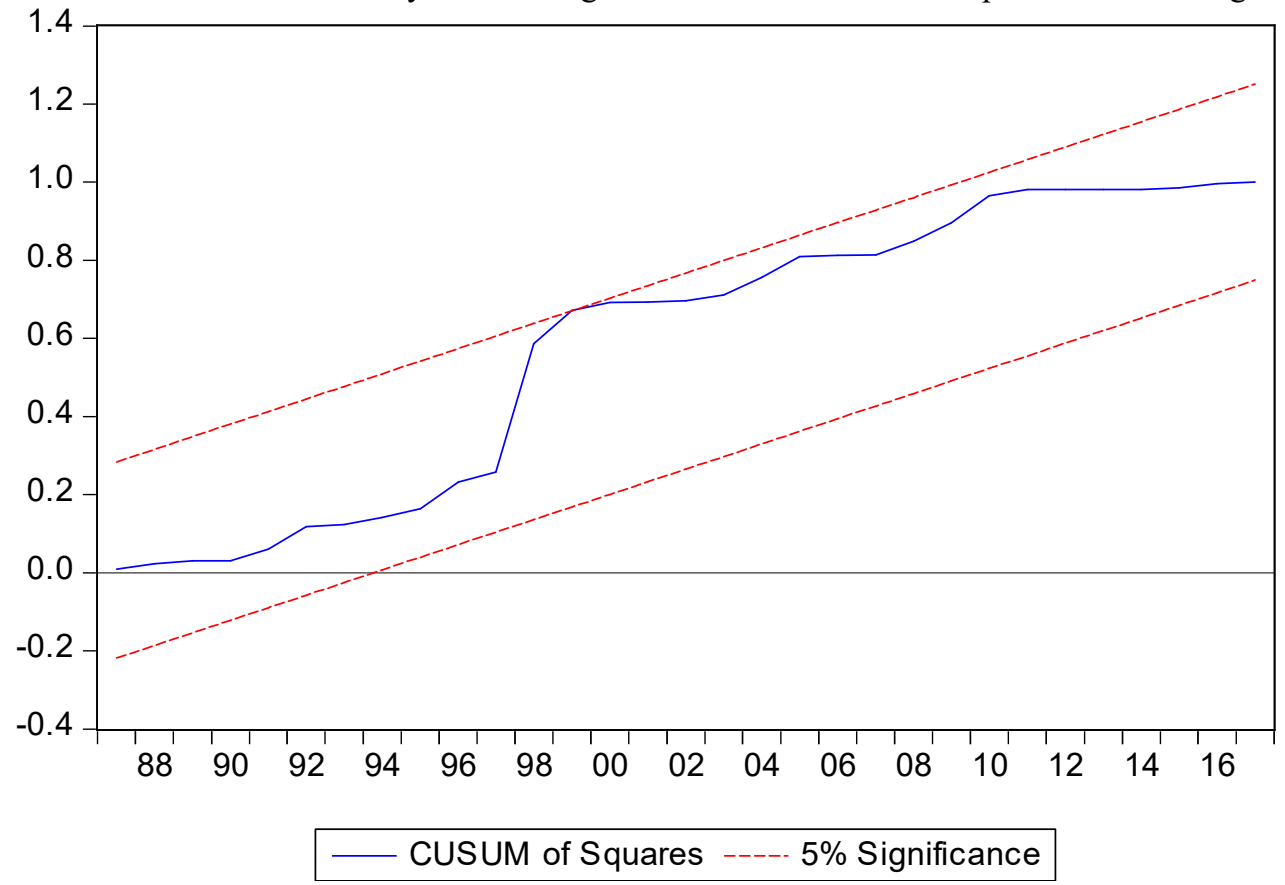

Figure 1. Cusum of Squares Test

Figure 2 shows the histogram-normality test. The values of skewness and kurtosis are 0.8318 and 2.8041 respectively. The distribution is positively skewed. A positively skewed distribution indicates that the residuals are clustered to the left, with the tail extending to the right. The non-normality is indicated by the presence of an outlier. The skewness and kurtosis are 0 in a normal distribution. Since the skewness and kurtosis are farther away from 0 , we conclude that the data are not normally distributed. 


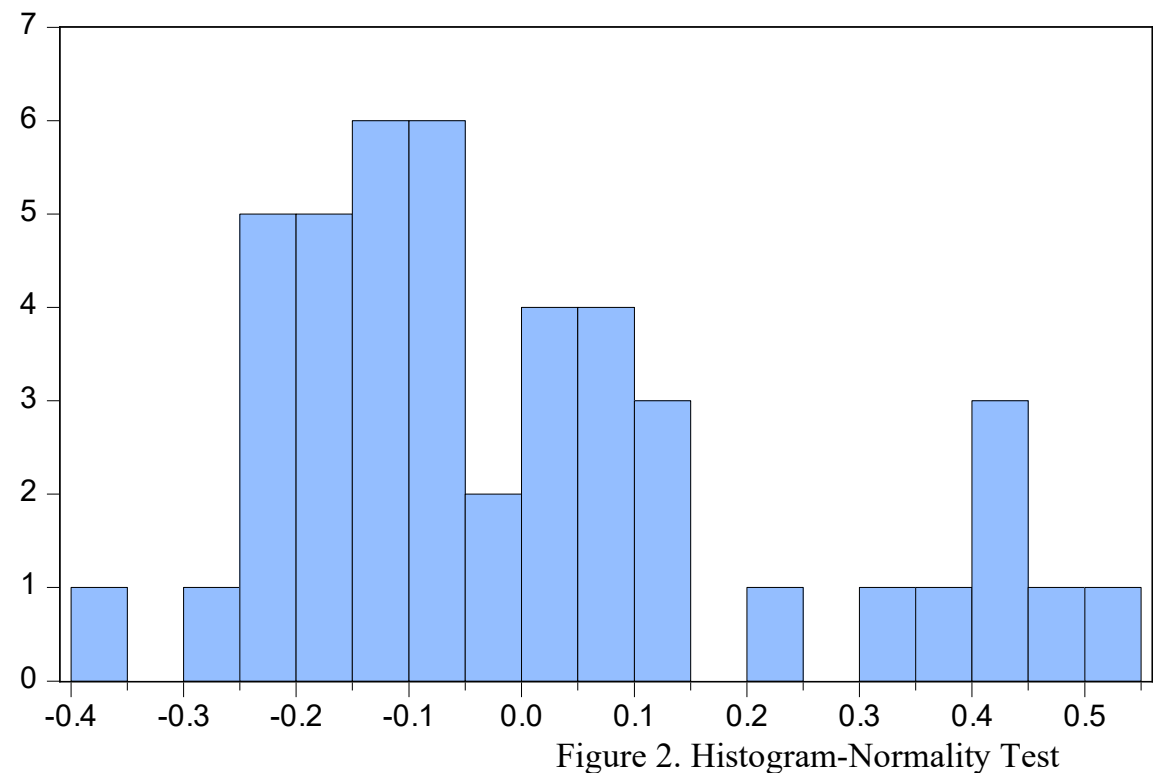

\section{Series: Residuals \\ Sample 19732017 \\ Observations 45}

$\begin{array}{lr}\text { Mean } & 3.70 \mathrm{e}-15 \\ \text { Median } & -0.060840 \\ \text { Maximum } & 0.512570 \\ \text { Minimum } & -0.357566 \\ \text { Std. Dev. } & 0.224764 \\ \text { Skewness } & 0.831769 \\ \text { Kurtosis } & 2.804051\end{array}$

Jarque-Bera $\quad 5.260785$

Probability $\quad 0.072050$

\subsection{Dummy Variable Regression Results}

Table 3 presents the dummy variable regression results of D(LGDP). The differential intercept is 0.6194 and its $p$ value is 0.7685 . The differential slope coefficient is 7.8472 and its $p$-value is 0.0000 . The results show that the differential intercept is positive but statistically insignificant and differential slope coefficient is positive and statistically significant, strongly suggesting that the exchange rate-economic growth regressions for the fixed and flexible exchange rate regimes are different. This is a case of dissimilar regressions. The results indicate that the difference in the regressions for the two time periods is because of differences in the slope coefficients. The slope coefficient for a flexible exchange rate regime is greater than the slope coefficient for a fixed exchange rate regime by 7.8472 units.

The calculated F-statistic is 1097.394 . The tabulated F-statistic is 2.42 at 5 percent level of significance and at 6 and 38 degrees of freedom. The calculated F-statistic is greater than the tabulated F-statistic. Therefore, this study rejects the hypothesis that the parameters are stable for the entire data set and concludes that there is an evidence of structural instability. In other words, the shift from a fixed exchange rate regime to a flexible exchange rate regime leads to an increase in exchange rate and economic growth in Nigeria.

The regression coefficient of exchange rate (EXR) is 0.4352 and its p-value is 0.0000 . The regression coefficient of EXR is positive and it is statistically significant. These results show that the switch from a fixed exchange rate regime to a flexible exchange rate regime leads to an increase in exchange rate and the depreciation of exchange rate has significant positive impact on economic growth in Nigeria.

The regression coefficient of gross domestic investment (GDI) is 0.7156 and its p-value is 0.0000 . The regression coefficient of GDI is positive and it is statistically significant. This result shows that GDI has significant positive impact on economic growth in Nigeria. The finding confirms the Keynesian proposition that economic growth increases as investment increases.

The regression coefficient of net exports (NEX) is $1.39 \mathrm{E}-13$ and its p-value is 0.2600 . The regression coefficient of NEX is positive but it is statistically insignificant. This result indicates that NEX has insignificant positive impact on economic growth in Nigeria. The NEX has insignificant positive impact on economic growth because of low level of exports and over-dependence by Nigerians on imported goods and services for virtually everything we produce and consume.

The regression coefficient of financial sector development (FSD) is 0.1409 and its p-value is 0.2273 . The regression coefficient of FSD is positive but it is statistically insignificant. This result indicates that FSD has insignificant positive impact on economic growth in Nigeria. The FSD has insignificant positive impact on economic growth because the domestic credit provided by banks to the private sector is inadequate and this is as a result of inadequate capital and high nonperforming assets of the banking sector in Nigeria. 
Table 3. Dummy Variable Regression Results of D(LGDP)

\begin{tabular}{|l|l|l|l|l|}
\hline Variable & Coefficient & Std Error & t-Statistic & Prob. \\
\hline C & 0.0030 & 0.1853 & 0.0161 & 0.9872 \\
\hline DUM & 0.6194 & 2.0925 & 0.2960 & 0.7685 \\
\hline D(LEXR) & 0.4352 & 0.0738 & 5.8957 & 0.0000 \\
\hline D(LGDI) & 0.7156 & 0.0507 & 14.1166 & 0.0000 \\
\hline D(LNEX) & $1.39 \mathrm{E}-13$ & $1.21 \mathrm{E}-13$ & 1.1434 & 0.2600 \\
\hline $\mathrm{D}($ LFSD) & 0.1409 & 0.1148 & 1.2273 & 0.2273 \\
\hline $\mathrm{D}[$ L(DUM*EXR*GDI*NEX*FSD)] & 7.8472 & 1.1643 & 6.7401 & 0.0000 \\
\hline
\end{tabular}

R-Squared: 0.99 Standard Error: 0.24 F-statistic: 1097.39 Durbin-Watson stat: 1.54

Source: Authors' Computation

\section{Conclusions}

The exchange rate-economic growth regressions for the fixed and flexible exchange rate regimes are different. The difference in the regressions for the two time periods is because of differences in the slope coefficients. The slope coefficient for a flexible exchange rate regime is greater than the slope coefficient for a fixed exchange rate regime. We reject the hypothesis that the parameters are stable for the entire data set and conclude that there is an evidence of structural instability. The switch from a fixed exchange rate regime to a flexible exchange rate regime leads to an increase in exchange rate and the depreciation of exchange rate has significant positive impact on economic growth in Nigeria. A flexible exchange rate regime would promote economic growth more than a fixed exchange rate regime. We recommend the sustainability of a flexible exchange rate regime that has been in operation since 1986 in order to increase economic growth in Nigeria. A confirmatory study should be conducted by adherents of a fixed exchange rate regime if they are in doubt of the research outcomes of this investigation.

\section{References}

Aizenman, J. (1994), "Monetary and Real Shocks, Productive Capacity and Exchange Rate Regimes”, Economica, 61(244),407-34.

Akpan, E. O. \& Atan, J. A. (2012), "Effects of exchange rate movements on economic growth in Nigeria", $C B N$ Journal of Applied Statistics, 2(2), 1-14.

Bailliu, J. (2000), "Private Capital Flows, Financial Development, and Economic Growth in Developing Countries", Bank of Canada Working Paper, No. 2000-15.

Bailliu, J., Lafrance, R. \& Perrault, J. (2002), “Does Exchange Rate Policy Matter for Growth?”, Bank of Canada Working Paper, No. 2002-17, 1-43.

Barro, R. J. \& Sala-i-Martin, X. X. (1995), “Economic Growth”, Montreal: McGraw-Hill, New York.

Bleaney, M. \& Francisco, M. (2007), "Exchange Rate Regime, Inflation and Growth in Developing Economies: An Assessment", The B.E. Journal of Macroeconomics, 7(1), 1-18.

Bohm, H. \& Funke, M. (2001), "Does the Nominal Exchange Rate Regime Matter for Investment?", CESifo Working Paper, No. 578.

Chang, R. \& Velasco A. (2000), "Exchange-Rate Policy for Developing Countries", The American Economic Review, 90 (2), 71-75.

Dickey, D. A. \& Fuller W. A. (1979), "Distribution of the Estimators for Autoregressive Time Series with a Unit Root", Journal of the American Statistical Association, 74, 427-431.

Dooley, M. P. (1994), "Are Recent Capital Inflows to Developing Countries a Vote For or Against Economic Policy Reforms?",Santa Cruz Working Paper, No. 295, Department of Economics, University of California.

Edwards, S. (1993), "Trade Policy, Exchange Rates and Growth", National Bureau of Economic Research Working Paper, No. 4511.

Eneji, M. A., Nanwul D. F., Eneji, A. I., Anga R. \& Dickson V. (2018), "Effect of Exchange Rate Policy and its Volatility on Economic Growth in Nigeria", International Journal of Advanced Studies in Economics and Public Sector Management,6(2), 166-190.

Eze, T. C. \& Okpala, C. S. (2014), "Quantitative Analysis of the Impact of Exchange Rate Policies on Nigeria's Economic Growth: A Test of Stability of Parameter Estimates", International Journal of Humanities and Social Science,4(7), 265-272.

Ghosh, A. R., Ostry, J. D., Gulde, A. M. \& Wolf, H. C. (1997), "Does the Nominal Exchange Rate Regime Matter?", NBER Working Paper, 5874.

Hausmann, R., Gavin, M., Pages-Serra, C. \& Stein, E. (1999), "Financial Turmoil and the Choice of an Exchange Rate Regime", Working Paper, No. 400, Washington: Inter-American Development Bank.

Huang, H. \& Malhorta, P. (2004), "Exchange Rate Regimes and Economic Growth: Evidence from Developing Asian and Advanced European Economies", IMF Working paper series, p.1- 32. 
IMF (2013), “Annual Report on Exchange Arrangements and Exchange Restrictions”, Washington, DC: IMF, Publication Services.

Jakob, B. (2016), "Impact of Exchange Rate Regimes on Economics Growth", Undergraduate Economic Review, Volume 12, Issue 1, Article 11,1-23.

Johansen, S. (1988), "Statistical Analysis of Co-integrating Vectors", Journal of Economic Dynamics and Control, $12,231-54$.

Keynes, J. M. (1936), “The General Theory of Employment, Interest and Money”, Harcourt, Brace and Co., New York.

Levine, R. (1997), "Financial Development and Economic Growth: Views and Agendas", Journal of Economic Literature, 35(2), 688-726.

Levy-Yeyati, E. \& Sturzenegger, F. (2003), “To Float or to Fix: Evidence on the Impact of Exchange Rate Regimes on Growth", American Economic Review, 93, 1173-93.

McConnell C. R. \& Brue S. L. (2005), “Macroeconomics: Principles, Problems and Policies”, Sixteenth Edition, McGraw-Hill/Irwin, New York.

Miles, W. (2006), “To Float or Not To Float? Currency Regimes and Growth”, Journal of Economic Development, 31(2), 91-105.

Moreno, R. (2001), "Pegging and Stabilization Policy in Developing Countries", Economic Review of the Federal Reserve Bank of San Francisco, 12(99): 17-29.

Nilsson, K. \& Nilsson, L. (2000), "Exchange Rate Regimes and Export Performance of Developing Countries", World Economy, 23(3), 331-49.

Obadan, M. I. (2006), "Overview of Exchange Rate Management in Nigeria from 1986 to Date", Bullion: Publication of the Central Bank of Nigeria, 30(3), 1-9.

Obi, K. O., Oniore, J. O. \& Nnadi, K. U. (2016), "The Impact of Exchange Rate Regimes on Economic Growth in Nigeria", Journal of Economics and Sustainable Development,7(12), 115-127.

Soludo, C. C. (1993), "Theoretical Basis for the Structural Adjustment Programme in Nigeria: Two Alternative Critiques", The Nigerian Journal of Economic and Social Studies, 35(1), 49-63.

Stotsky, J. G., Ghazanchyan, M., Adedeji, O. \& Maehle, N. (2012), "The Relationship between the Foreign Exchange Regime and Macroeconomic Performance in Eastern Africa", IMF Working Paper, WP/12/148.

Yougbaré, L. (2008), "Exchange Rate Regimes, Growth and Volatility: An Empirical Reappraisal”, Centre for Studies and Research on International Development (CERDI) - CNRS and University of Auvergne, France. 